\title{
Analytical study to assess fetal and perinatal outcome in booked and unbooked obstetric cases
}

\author{
Sapna Chourasia ${ }^{1}$, Kamlesh Yadav $^{2}$
}

\begin{abstract}
${ }^{1}$ Department of Obstetrics and Gynecology, Sri Aurobindo Medical College and PGI, Indore, Madhya Pradesh, India ${ }^{2}$ Department of Obstetrics and Gynecology, Sardar Patel Medical College, Bikaner, Rajasthan, India
\end{abstract}

Received: 28 October 2016

Accepted: 29 November 2016

\section{*Correspondence:}

Dr. Sapna Chourasia,

E-mail: drsapnachourasia@gmail.com

Copyright: (c) the author(s), publisher and licensee Medip Academy. This is an open-access article distributed under the terms of the Creative Commons Attribution Non-Commercial License, which permits unrestricted non-commercial use, distribution, and reproduction in any medium, provided the original work is properly cited.

\begin{abstract}
Background: The high perinatal mortality rates are indicators of the poor state of health services and it is pertinent to determine the relationship between the booking status of mother and fetal outcomes.

Methods: In the present randomized prospective study of 400 unbooked (study group) obstetric cases were evaluated and compared with 400 booked (control group) obstetric cases over a period of one year.

Results: Perinatal outcomes of women in study group were significantly poorer than women in control group due to high preterm delivery, LBW, with low Apgar score at five minutes, with more NICU admission due to RDS, with high perinatal mortality in term of IUD, early neonatal deaths in study group.

Conclusions: Findings of the study will help the programmers and service providers in identifying areas where emphasis has to be given in the development of strategies that will promote the utilization of antenatal services, to reduce adverse perinatal and fetal outcome.
\end{abstract}

Keywords: Booked cases, Fetal outcome, Maternal mortality, Obstetric care, Unbooked cases

\section{INTRODUCTION}

Maternal health refers to the health of the mother during pregnancy, childbirth and the postpartum period. ${ }^{1}$ Following the diagnosis of pregnancy, the first prenatal visit (booking visit) should occur during the first trimester. Consequently, a pregnant women is said to have "booked" if, excluding the booking visit, she attended at least three antenatal clinic visits and received at least one dose of tetanus immunization. She is also consider " booked" if, beside the booking visit, she makes a minimum of two more visits lasting not more than two weeks before delivery. ${ }^{2}$

The high perinatal mortality rates in India continue to be issues of concern as they are indicators of the poor state of health services with the implication that relevant health-related millennium development goals may not be achieved in the country. In light of current maternal and perinatal mortality situation in India, it is pertinent to determine the relationship between the booking status of mother and fetal outcomes. Hence this study was aimed to determine perinatal and fetal outcomes in booked and unbooked mothers.

\section{METHODS}

The present study was a randomized prospective study conducted from July 2012 to July 2013 at Department of Obstetrics and Gynaecology, S.P. Medical College and A.G. of Hospitals, Bikaner Rajasthan, a tertiary care hospital. Eight Hundred patients were included in the study and were divided into two groups. Study group consist of unbooked women $(n=400)$ and control group consist of booked women $(n=400)$. All pregnant women with singleton pregnancy having gestational age more than 28 weeks both, unbooked and booked, attending obstetric emergency for delivery and women who 
delivered at home or at periphery and brought to the hospital for emergency obstetric care in our center were included in our study. Booked women were defined as those who had at-least three antenatal visits at our center, while un-booked women were those who have no prenatal care at all throughout the pregnancy, those who registered at our unit but had less than two antenatal clinic visits, and patients referred as emergency from other facilities. Structured questionnaire was administered to cases, and a detailed history was obtained which included age, socioeconomic status, and residence, education status and booking status. Obstetric history regarding gravida, parity, LMP, period of gestation, chief complaints for which she was admitted and pregnancy related complications, significant clinical events in previous pregnancy and history of any medical and surgical illness was obtained. Neonatal outcome such as gestational age, Apgar scores, birth weight, and perinatal mortality etc. were documented. All patients were followed till discharge.

\section{RESULTS}

Table 1: Distribution of cases according to their pregnancy outcomes.

\begin{tabular}{|c|c|c|c|c|c|c|}
\hline \multirow[t]{2}{*}{ Pregnancy outcomes } & \multicolumn{2}{|c|}{ Study group } & \multicolumn{2}{|c|}{ Control group } & \multirow[t]{3}{*}{$\chi^{2}$} & \multirow[t]{2}{*}{ p- value } \\
\hline & No. & $\%$ & No. & $\%$ & & \\
\hline \multicolumn{6}{|l|}{ Gestational age (weeks) } & \\
\hline Preterm $<37$ week & 97 & 24.25 & 62 & 15.50 & \multirow[t]{4}{*}{10.21} & \multirow[t]{4}{*}{0.001} \\
\hline Term >37 week & 293 & 73.25 & 338 & 84.50 & & \\
\hline Not known & 10 & 2.50 & 0 & 0 & & \\
\hline Total & 390 & 100 & 400 & 100 & & \\
\hline \multicolumn{7}{|l|}{ Birth weight (kg) } \\
\hline$<2.5$ & 176 & 44.00 & 97 & 24.25 & \multirow[t]{5}{*}{42.45} & \multirow[t]{5}{*}{0.0001} \\
\hline $2.5-3.5$ & 182 & 45.50 & 276 & 69.00 & & \\
\hline$>3.5$ & 32 & 8.00 & 27 & 6.75 & & \\
\hline Not known & 10 & 2.5 & 0 & 0 & & \\
\hline Total & 400 & 100 & 400 & 100 & & \\
\hline Mean \pm SD & \multicolumn{2}{|c|}{$2.616 \pm 0.56$} & \multicolumn{2}{|c|}{$2.71 \pm 0.47$} & $\mathrm{t}=2.57$ & 0.01 \\
\hline
\end{tabular}

Table 2: Distribution of cases according to Apgar score at 1 minute.

\begin{tabular}{|c|c|c|c|c|c|c|}
\hline \multirow{2}{*}{$\begin{array}{l}\text { Apgar } \\
\text { score }\end{array}$} & \multicolumn{2}{|c|}{$\begin{array}{l}\text { Study } \\
\text { group }\end{array}$} & \multicolumn{2}{|c|}{$\begin{array}{l}\text { Control } \\
\text { group }\end{array}$} & \multirow[t]{2}{*}{$x^{2}$} & \multirow{2}{*}{$\begin{array}{l}\mathbf{P} \\
\text { Value }\end{array}$} \\
\hline & No & $\%$ & No. & $\%$ & & \\
\hline$<7$ & 122 & 30.50 & 78 & 19.50 & \multirow{4}{*}{13.88} & \multirow{4}{*}{0.0002} \\
\hline$>7$ & 268 & 67.00 & 322 & 80.50 & & \\
\hline $\begin{array}{l}\text { Not } \\
\text { known }\end{array}$ & 10 & 2.50 & 0 & 0 & & \\
\hline Total & 400 & 100 & 400 & 100 & & \\
\hline $\begin{array}{l}\text { Mean } \\
\pm S D\end{array}$ & \multicolumn{2}{|c|}{$6.91 \pm 2.57$} & \multicolumn{2}{|c|}{$7.71 \pm 1.95$} & $\mathrm{t}=4.95$ & $<0.001$ \\
\hline
\end{tabular}

Eight Hundred patients were studied which comprised of study group of unbooked women $(n=400)$ and control group of booked women $(n=400) .24 .25 \%$ of women in study group gave birth to preterm babies. $44 \%$ of women in study group had babies with birth weight less than 2.5 kg.(Table 1) The Apgar score at one minute was less than 7 in $30.50 \%$ of babies born to women in study group while this was seen in $19.50 \%$ of babies born to women in control group. (Table 2) The Apgar score at five minute was less than 7 in $12 \%$ of babies born to women in study group, while this was seen in $5.50 \%$ of babies born to women in control group. (Table 3) $22 \%$ babies of women in study group had admission in neonatal ICU, while $16.25 \%$ babies of women in control group had admission in neonatal ICU (Table 4).

Table 3: Distribution of cases according to Apgar score at 5 minutes.

\begin{tabular}{|c|c|c|c|c|c|c|}
\hline \multirow{2}{*}{$\begin{array}{l}\text { Apgar } \\
\text { score }\end{array}$} & \multicolumn{2}{|c|}{$\begin{array}{l}\text { Study } \\
\text { group }\end{array}$} & \multicolumn{2}{|c|}{$\begin{array}{l}\text { Control } \\
\text { group }\end{array}$} & \multirow[t]{2}{*}{$x^{2}$} & \multirow{2}{*}{$\begin{array}{l}\mathbf{P} \\
\text { Value }\end{array}$} \\
\hline & No & $\%$ & No. & $\%$ & & \\
\hline$<7$ & 48 & 12 & 22 & 5.50 & \multirow{4}{*}{10.50} & \multirow{4}{*}{0.0012} \\
\hline$>7$ & 342 & 85.50 & 378 & 94.50 & & \\
\hline $\begin{array}{l}\text { Not } \\
\text { known }\end{array}$ & 10 & 2.50 & 0 & 0 & & \\
\hline Total & 400 & 100 & 400 & & & \\
\hline $\begin{array}{l}\text { Mean } \\
\pm \text { SD }\end{array}$ & \multicolumn{2}{|c|}{$7.99 \pm 2.27$} & \multicolumn{2}{|c|}{$8.55 \pm 1.41$} & $\mathrm{t}=4.19$ & $<0.001$ \\
\hline
\end{tabular}

Neonatal morbidity was $17.18 \%$ among babies born to women in study group, while $15.50 \%$ among babies born to women in control group. Respiratory distress syndrome (5.38\%), birth asphyxia (4.62\%) and convulsions were higher in babies of study group, while IUGR (5.48\%), meconium aspiration syndrome (3.81\%), 
jaundice $(3.13 \%)$ were higher in babies of control group. (Table 5) Among the babies of un-booked mothers 5.75\% of babies had intrauterine deaths, $0.75 \%$ of babies had still birth and $5 \%$ of babies had early neonatal deaths, while among the babies of booked mothers $1.75 \%$ babies had IUD, $0.25 \%$ babies had still birth, and $2.75 \%$ babies had early neonatal deaths respectively (Table 6).

\section{DISCUSSION}

This study shows that perinatal outcomes in unbooked mothers were significantly poorer than in booked mothers. It is observed that labour complications have very strong effects on perinatal mortality complications, such as increased risk of perinatal death and rate of perinatal death is higher in home delivery. ${ }^{3,4}$ It is a tragic situation that most of feto-maternal morbidity and mortality are not caused by disease but occur during or after labour which is a natural process.

Table 4: Distributions of cases according to neonatal ICU admissions.

\begin{tabular}{|c|c|c|c|c|c|c|}
\hline \multirow[t]{2}{*}{$\begin{array}{l}\text { NICU } \\
\text { Admission }\end{array}$} & \multicolumn{2}{|c|}{$\begin{array}{l}\text { Study } \\
\text { group }\end{array}$} & \multicolumn{2}{|c|}{$\begin{array}{l}\text { Control } \\
\text { group }\end{array}$} & \multirow[t]{2}{*}{$\chi^{2}$} & \multirow[t]{2}{*}{$\begin{array}{l}\text { p- } \\
\text { value }\end{array}$} \\
\hline & No. & $\%$ & No. & $\%$ & & \\
\hline Nil & 302 & 75.50 & 335 & 83.75 & \multirow[t]{4}{*}{4.64} & \multirow[t]{4}{*}{0.03} \\
\hline Yes & 88 & 22.00 & 65 & 16.25 & & \\
\hline Not known & 10 & 2.50 & 0 & 0 & & \\
\hline Total & 400 & 100 & 400 & 100 & & \\
\hline
\end{tabular}

Table 5: Distributions of cases according to fetal morbidity.

\begin{tabular}{|c|c|c|c|c|c|c|}
\hline \multirow[t]{2}{*}{ Fetal morbidity } & \multicolumn{2}{|c|}{ Study group } & \multicolumn{2}{|c|}{ Control group } & \multirow[t]{2}{*}{$x^{2}$} & \multirow[t]{2}{*}{ p- Value } \\
\hline & No. & $\%$ & No. & $\%$ & & \\
\hline Nil & 323 & 82.82 & 338 & 84.50 & & \\
\hline RDS & 21 & 5.38 & 8 & 2 & 6.28 & 0.01 \\
\hline Birth asphyxia & 18 & 4.62 & 11 & 2.75 & 1.53 & 0.21 \\
\hline Congenital malformation & 7 & 1.78 & 5 & 1.25 & 0.21 & 0.64 \\
\hline IUGR & 6 & 1.50 & 15 & 3.75 & 5.48 & 0.01 \\
\hline MAS & 6 & 1.50 & 14 & 3.50 & 5.32 & 0.02 \\
\hline Neonatal sepsis & 4 & 1.00 & 4 & 1 & 0 & 0 \\
\hline Convulsion & 4 & 1.00 & 0 & 0 & 3.81 & 0.05 \\
\hline Jaundice & 1 & 0.26 & 5 & 1.25 & 3.13 & 0.07 \\
\hline Not known & 10 & 2.50 & 0 & 0 & & \\
\hline Total & 400 & 100 & 400 & 100 & & \\
\hline
\end{tabular}

Table 6: Distribution of cases according to perinatal mortality.

\begin{tabular}{|lllllll|}
\hline Perinatal mortality & \multicolumn{2}{l}{ Study group } & \multicolumn{2}{l|}{ Control group } & $\chi^{2}$ & p- value \\
\cline { 2 - 6 } & No. & $\mathbf{\%}$ & No. & \% & & \\
\hline No mortality & 344 & 86.00 & 386 & 96.50 & & 0.002 \\
\hline IUD & 23 & 5.75 & 7 & 1.75 & 9.29 & 0.30 \\
\hline Still birth & 3 & 0.75 & 1 & 0.25 & 0.006 & 0.004 \\
\hline Early neonatal death & 20 & 5.00 & 6 & 2.75 & 0.0016 & \\
\hline Not known & 10 & 2.5 & 0 & 0 & & \\
\hline Total & 400 & 100 & 400 & 100 & & \\
\hline
\end{tabular}

As compared to booked mothers, unbooked mothers were 1.5 times more likely to delivers preterm babies $(24.25 \%$ vs $15.5 \%$; $\mathrm{p}<0.001)$ and low birth weight babies $(44 \% \mathrm{v} / \mathrm{s}$ $24.25 \% ; \mathrm{p}<0.01)$. This shows that unbooked status contributes to maternal undernourishment and inadequate care during pregnancy which resulted in obstetric complication thus compromising both mother and baby. Various maternal complication such as anemia, antepartum hemorrhage (APH), PPROM, and preeclampsia and eclampsia, preterm labour during pregnancy significantly increased the risk of LBW outcomes. These findings were consistent with findings of other studies. $^{5-9}$

This study shows that $30.50 \%$ babies of unbooked mothers and $19.50 \%$ babies of booked mother had Apgar score $<7$ at one minute $(\mathrm{p}<0.002)$ while $12 \%$ babies of unbooked mothers and $5.50 \%$ babies of booked mothers had Apgar score of $<7$ at five minute. It indicates that as compared to booked mothers, babies of unbooked 
mothers were 1.5 times more likely to have birth asphyxia $(p<0.002)$. This was comparable with other studies. ${ }^{8,9}$

In present study $22 \%$ neonates from study group and $16.25 \%$ neonates from control group were admitted in NICU ( $\mathrm{p}<0.03)$. This was comparable to other studies. $^{7,8,10}$

In present study neonatal morbidity were encountered in $16.75 \%$ neonates of study group and $15.5 \%$ of neonates in control group. In study group, most common cause being RDS (5.38\%) followed by birth asphyxia (4.62\%), gross congenital malformation (1.78\%), IUGR (1.5\%), MAS $(1.5 \%)$, neonatal sepsis $(1 \%)$ while in control group, most common cause of neonatal morbidity was IUGR $(3.75 \%)$ and MAS $(3.50 \%)$ (Because high proportion of cases with hypertension), Birth asphyxia $(2.75 \%)$. This shows positive correlation between lack of proper antenatal care and adverse pregnancy outcomes in unbooked than booked women. This was comparable with other studies. ${ }^{5,7-10}$

In present study perinatal mortality was encountered in $11.80 \%$ of cases in study group and $3.50 \%$ in control groups. There was statistically significant difference between babies of unbooked and booked women in term of neonatal ICU admissions ( $22 \%$; vs $15.25 \%$ p $<0.01)$ intrauterine death (IUD) $(5.75 \%$ vs $1.75 \%$; $<<0.0 .01)$, and early neonatal deaths ( $5 \%$ vs $2.75 \%$; $<<0.01)$.

\section{CONCLUSION}

Perinatal outcomes of women in study group were significantly poorer than women in control group due to high preterm delivery, LBW, with low Apgar score at five minutes, with more NICU admission due to RDS, with high perinatal mortality in term of IUD, early neonatal deaths in study group. This study is relevant, because the findings of the study will help the programmers and service providers in identifying areas where emphasis has to be given in the development of strategies that will promote the utilization of antenatal services, in particular, so as to reduce the occurrence of perinatal mortality, morbidity and their consequences.
Funding: No funding sources Conflict of interest: None declared

Ethical approval: The study was approved by the Institutional Ethics Committee

\section{REFERENCES}

1. Abou Zahr C, Wardlaw T. Maternal mortality in 2000: estimates by WHO, UNICEF and UNFPA. Geneva: 2001.

2. Ekele BA, Audu LR. Gestational age at first antenatal attendance in Sokoto, Northern Nigeria. Trop J Obstet Gynaecol. 1998;15:39-40.

3. Khan KS, Wojdyla D, Say L, Gulmezoglu AM, Look PFV. WHO analysis of causes of maternal deaths: a systematic review. Lancet. 2006;367:1066-74.

4. Kennare RM, Keirse MJ, Tucker GR, Chan AC. Perinatal death associates with planned home birth in Australia: population based study. BMJ. 2005;317:3848.

5. Pokharel HP, Lama GJ, Banerjee B, Paudel LS, PK Pokharel. Maternal and Perinatal outcome among the booked and unbooked pregnancies. International Journal of Gynecology and Obstetrics. 2007;88(2):16872.

6. Rani M, Bonu S, Harvey S. Differentials in the quality of antenatal care in India. Int J Quality Healt Care. 2008;20(1):62-71.

7. Chigbu B, Onwere S, Kamanu CI, Aluka C, Okoro O, Adibe E. Pregnancy Outcome in Booked and Unbooked Mothers in South Eastern Nigeria. East Afr Med J. 2009;86(6):267-.

8. Gonied AS. Maternal Complications and Perinatal Outcomes in Booked and Unbooked Mothers. Journal of American Science. 2011;7(10):792-6.

9. Kaur J, Kaur K. Does an Antenatal Care make a difference? Hum Bio Rev. 2013;2(2):120-35.

10. Owolabi AT, Fatusi AO, Kuti O, Adeyemi A, Faturoti SO, Obiajuwa PO. Maternal complications and perinatal outcomes in booked and unbooked Nigerian mothers. Singapore Med J. 2008;49(7):526-31.

Cite this article as: Chourasia $\mathrm{S}$, Yadav $\mathrm{K}$.

Analytical study to assess fetal and perinatal outcome in booked and unbooked obstetric cases. Int J Reprod Contracept Obstet Gynecol 2017;6:203-6. 